\title{
Academic text: The importance of the use and comprehension of hedges
}

\section{Tony Dudley-Evans}

\section{(2) OpenEdition \\ 1 Journals}

Electronic version

URL: https://journals.openedition.org/asp/4054

DOI: 10.4000/asp.4054

ISSN: 2108-6354

\section{Publisher}

Groupe d'étude et de recherche en anglais de spécialité

\section{Printed version}

Date of publication: 1 December 1994

Number of pages: 131-139

ISSN: 1246-8185

\section{Electronic reference}

Tony Dudley-Evans, "Academic text: The importance of the use and comprehension of hedges", ASp

[Online], 5-6 | 1994, Online since 06 December 2013, connection on 21 September 2021. URL: http:// journals.openedition.org/asp/4054 ; DOI: https://doi.org/10.4000/asp.4054

This text was automatically generated on 21 September 2021.

Tous droits réservés 


\title{
Academic text: The importance of the use and comprehension of hedges
}

\author{
Tony Dudley-Evans
}

1 In my paper I wish to take an aspect of the research in ESP in what Ann Johns (this volume) refers to as the 'high culture' of LSP, the academic article and examine how it works and then explore some teaching material that attempts to de-mystify it for students. The topic is hedging, which refers to the process by which the writer or writers distance themselves from the knowledge claim that they wish to make. This is the normal explanation of why writers use hedging which I shall come to later, but let us be clear how we recognise hedging in academic text.

The linguistic features are:

1. The use of modal verbs, e.g., may, might, can, could, would

2. The use of semi-auxiliary verbs such as seem to and appear to

3. The use of adverbs such as probably, possibly, and adjectives such as likely, plausible, possible, feasible, etc.

4. The use of non-factive verbs to report claims, i.e., verbs such as suggest, indicate, speculate, imply.

5. Giving a statement personal attribution as in I would like to argue that

6. Attribution of claims to an impersonal agency such as the results, the study, the observations as in phrases like The results suggest that...

7. When criticising, invoking a general rule or category, as in The idea that cells would do so to increase their potential for future evolution is not a Darwinian one. Given the canonical status of Darwin in microbiology, to state that something is 'not Darwinian' is to criticise the idea politely (Myers 1989).

2 The above are frequently referred to as 'shields' (Rounds 1982) by means of which writers adopt a defensive position. Rounds also suggests the category of 'approximators'. These are expressions of quantity, frequency, degree that render a statement less precise and therefore more cautious. So our 8th category is: The use of approximators such as approximately, roughly, quite, somewhat, considerably, etc. 

heavily used, especially in certain sections. Salager-Meyer (1994) found that $5.5 \%$ of the words in the introduction were hedges, $9 \%$ in Method and Materials section, $9.5 \%$ in the Results section and as many as $16 \%$ in the Discussion section. scientists learn to write in a cautious fashion as part of the process of socialisation into the academic community. This is undoubtedly true, but it begs the question of where the convention came from and what role hedging plays in the institutions of the academic world. It also fails to explain why in certain circumstances writers do not hedge their claims or criticisms.

6 Another explanation is that given by Selinker (1979). He states:

The well known practice of hedging in scientific writing is due to the fact that every attempt to explain a given phenomenon in a particular manner is open to an alternative explanation - generally introduced by the phrase 'but may be...'. There is a basic distinction between observed facts and interpretation. Observed facts are said strongly (e.g., we have found that)... Interpretations are invariably subject to 'may be'.

7 A number of researchers have also argued that hedges are in fact an appropriate use of vagueness in situations where precision may not be warranted. Skelton (1985: 41) observed that "it is important for students to learn to be confidently uncertain" and that hedges "are a resource, not a problem."

8 Swales (1990: 175) relates the notion to the expectations of the discourse community, describing hedges as devices for "projecting honesty, modesty and proper caution in selfreports and for diplomatically creating space in areas heavily populated by other researchers." Myers has developed the latter ideas and suggests that the use of hedging is in fact a politeness technique (Brown \& Levinson 1987) designed to show the proper respect for fellow researchers. Myers (1989: 5) states:

Scientific discourse consists of interactions among scientists in which the maintenance of face is crucial. We can see scientists as building alliances that define what knowledge is: the statement of the individual becomes a fact when it is accepted and used by a consensus of the community. In these interactions certain FTAs (Face Threatening Acts) are unavoidable and must be redressed with various politeness devices. Every scientific report makes a claim: in other words, it makes a statement that is to be taken as the article's contribution to knowledge. This is the statement that is implied when one cites the article. Most reports, in stating a claim, deny or supersede the claims of others... The making of a claim threatens the general scientific audience because it is a demand for communally granted credit... The claim also threatens the negative face of other researchers... because it implies a restriction on what they can do now.

9 So we have two varying views of the role of hedging, one is that they are a device for showing caution and for making appropriately guarded statements, the other is that they are used for reasons of politeness to show the appropriate deference to fellow researchers and similarly to show the general academic community that one has the necessary humility in making claims. Essentially, I do not see these views as being in contrast with one another, and a synthesis of the two approaches captures the phenomenon of hedging. In both cases hedging is seen as a resource. 
10 I would now like to move on to show a few exercises that deal with the question of hedging. In the teaching of academic writing I argue that there are essentially three types of exercise:

1. Raising rhetorical awareness

2. Manipulating relevant grammatical and lexical forms

3. Extension (Practice).

A good exercise will usually combine elements of at least two of these.

12 The first example is from a textbook in academic writing entitled Academic Writing for Graduate Students: Essential tasks and skills (Swales \& Feak 1994). This introduces the concept of strength of claim and then moves on to show in detail how strength of claim can be modified. It thus combines Type 1 and 2.

\section{Example 1}

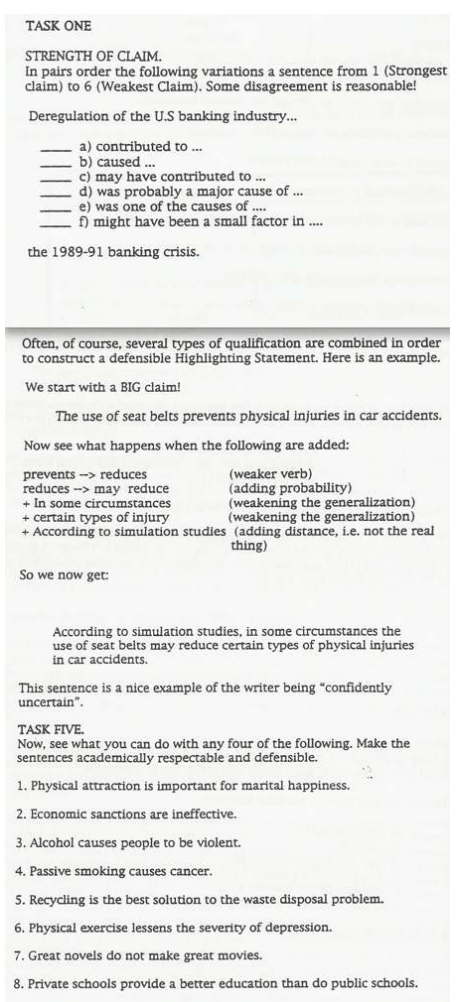

13 The second example presents the modal verbs and alternative expressions with possible and probable in the context of a section about explanations. This is taken from my own writing materials at the University of Birmingham. Here we have exercises Type 2 and 3. 
Example 2

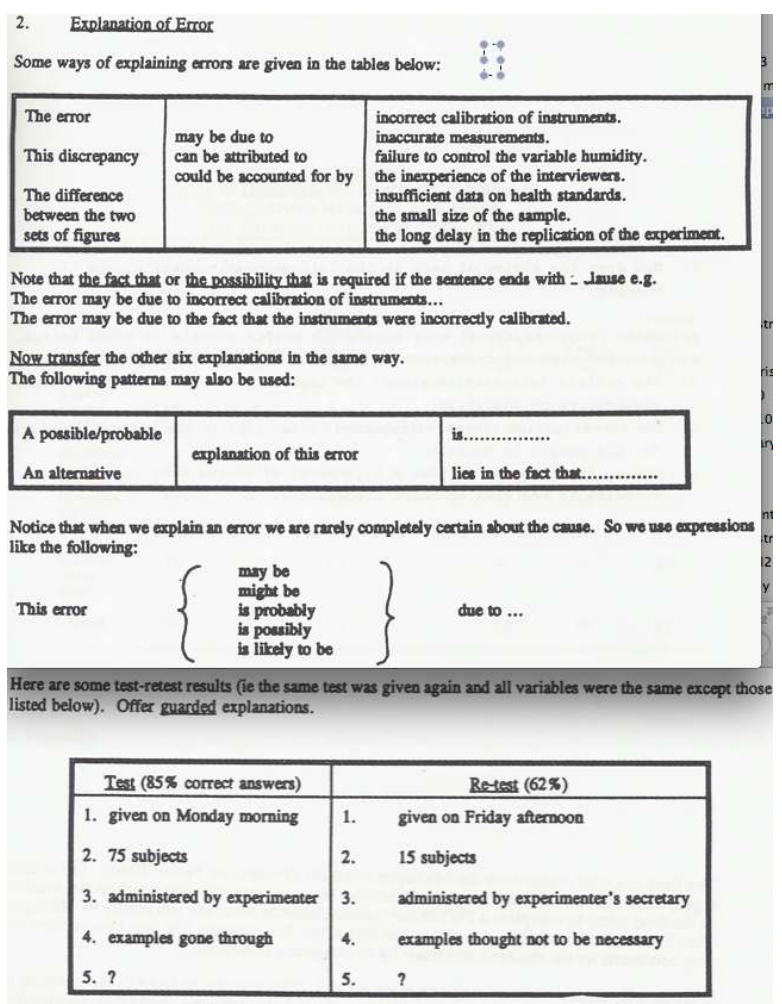

14 The third example, also from my writing materials, deals with the question of the relationship between the reporting verb and the strength of claim made.

Example 3

How does the choice of verbs in the following statements change the meaning:

a) Smith (suggests/shows) that Englishmen prefer animals to human beings.

b) A recent report (claims/proves) that alcohol is bad for your health.

c) The article (stresses/examines) the importance of increasing government expenditure on education.

d) The investigation (revealed/reported) great gaps in the medical provision for old people in Britain.

e) Jones (reported/found) that a high level of cholesterol leads to an increase in the risk of heart disease.

The final example is also from the Michigan materials. The student is presented with the table showing the differences between American and international students in the time taken to complete a PhD in the various departments at the University of Michigan. They then read a text analysis bearing on the data which they imagine that they have written and four comments on the student's text made by an imaginary supervisor. They have to decide whether each comment is valid. This goes to the heart of the question of what a research student writing up research has to do and also what the appropriate relationship is between the student and supervisor. Does the student have to accept everything that $\mathrm{s} / \mathrm{he}$ says?

This exercise combines elements of 2 and 3. 


\section{Example 4}

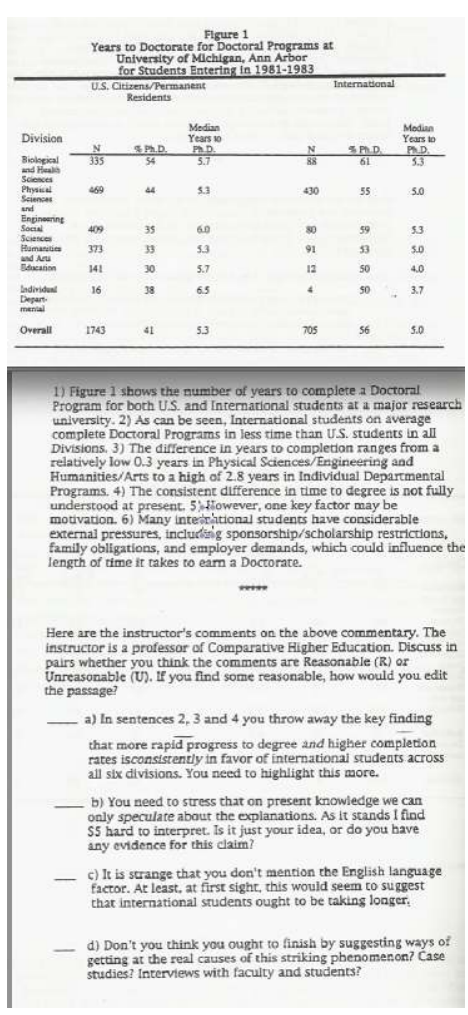

\section{Conclusion}

17 Hedging is a very interesting aspect of academic writing that lends itself to both linguistic and sociological investigation. The various definitions of hedging that have been presented in this short paper relate to the role of hedging for both individuals in choosing the appropriate stance for the knowledge claim that they wish to make and for discourse communities which expect certain behaviour on the part of writers. The definitions have also made use of the linguistic realisations of hedging. Both the linguistic and sociological aspects are concepts that are relatively easy to grasp and thus lend themselves to pedagogic treatment through the various exercise types that have been presented in the second half of this paper.

\section{BIBLIOGRAPHY}

Brown, P. and S. Levinson. 1987. "Universals in language usage: Politeness phenomena". In Goody, E. (ed.), Questions and Politeness: Strategies in social interaction. Cambridge: Cambridge University Press.

Lakoff, G. 1972. "Hedges: A study in meaning criteria and logic of fuzzy concepts". Journal of Philosophical Logic 2, 458-508.

Myers, G. 1989. “The pragmatics of politeness in scientific articles”. Applied Linguistics 10, 1-35. 
Prince, E.F., R.J. Frader and C.Bosk. 1982. “On hedging in physician-physician discourse”. In Di Prieto, J. (ed.), Linguistics and the Professions. Norwood, NJ: Ablex Publishing Corporation, 83 - 97.

Rounds, P. 1982. "Hedging in written academic discourse: Precision and flexibility”. Mimeo: The University of Michigan.

Salager-Meyer, F. 1994. "Hedges and textual communicative function in medical English written discourse". English For Specific Purposes 13/2.

Selinker, L. 1979. "On the use of informants in discourse analysis and language for specialized purposes". Iral 17, 189 - 215.

Skelton, J. 1988. “The care cnd maintenance of hedges”. ELT Journal 42: 37-44.

Swales, J.M. 1990. Genre Analysis. Cambridge: Cambridge University Press.

Swales, J.M. and C.B. Feak. 2004. Academic Writing For Graduate Students: Essential tasks and skills. Ann Arbor, MI: The University of Michigan Press.

\section{ABSTRACTS}

Writers of scientific articles often resort to hedging: the process by which they distance themselves from the knowledge claim that they wish to make. The reason for this may be the caution that is natural in academic writing. But there are a number of sociologically interesting alternative explanations. A number of exercises used to teach ESP students how to recognise and use the linguistic, psychological and sociological aspects of hedging are demonstrated.

Les auteurs d'articles scientifiques recourent fréquemment à la «précaution oratoire » (hedging), grâce à laquelle ils se distancient des affirmations qu'ils avancent. La raison d'être de cette pratique est la prudence inhérente à tout écrit scientifique. Il existe d'autres explications sociologiquement intéressantes. Plusieurs types d'exercices sont passés en revue, qui permettent à des étudiants d'anglais de spécialité de maîtriser les différents aspects linguistiques, psychologiques et sociologiques de la précaution oratoire.

\section{INDEX}

Mots-clés: article de revue scientifique, discours universitaire, précaution oratoire

Keywords: academic discourse, hedging, scientific journal article

\section{AUTHOR}

\section{TONY DUDLEY-EVANS}

Tony Dudley-Evans teaches at the University of Birmingham. a.m.dudley-evans@Bham.ac.uk 